\title{
Myths Broken or Sustained: Representation of Women Victims in Pakistani Media
}

\author{
Musarat Yasmin 1,2*, Ayesha Sohail1, Riaz Ahmed Mangrio² \\ ${ }^{1}$ Department of English, University of Azad Jammu and Kashmir, Muzaffarabad, Pakistan \\ ${ }^{2}$ Department of English, University of Gujrat, Gujrat, Pakistan \\ Email: ${ }^{\text {musarat.yasmin@uog.edu.pk, musaratalvi@hotmail.com }}$
}

Received 16 May 2015; accepted 11 July 2015; published 15 July 2015

Copyright (C) 2015 by authors and Scientific Research Publishing Inc.

This work is licensed under the Creative Commons Attribution International License (CC BY). http://creativecommons.org/licenses/by/4.0/

c) (i) Open Access

\begin{abstract}
Media is a cultural element that not only reflects the dominant attitudes of society but also shapes our approaches. Pakistani media mirrors the cultural influence on thoughts and ideas. This study intends to examine the current portrayal of women in crime reporting in Pakistani English print media. It also uncovers the change in media images, if there is any, over a period of seven years by comparing portrayal of women in 2007 with that in 2014. Data from widely read newspapers (Dawn and The News) for the period of March, 2007 and 2014 were collected and analyzed for linguistic choices using pragmatic approach. English media discourse is analyzed by following Mill's approach of Feminist Stylistics. Data are quantified to find the frequency of lexical choices being made. Result shows asymmetry in reporting female victims who are still described in terms of their marital status whereas male victims/perpetrators are represented in terms of their profession. Statistics show a slight change in naming victims and reporting their age in news.
\end{abstract}

\section{Keywords}

Crime Reporting in Media, Discourse Analysis, Feminist Stylistics, Media Biasness

\section{Introduction}

The press, being a powerful tool of socialization, plays a crucial role in the propagation of information. With this power of access, it can influence people's perceptions, beliefs and attitudes. It (mis)represents reality and in spite of being a mirror reflecting truth, it acts like a prism bending and distorting the view of the world [1]. A deep insight into the content and language of the media enables us to assess its contribution to gender issues. Gendered messages that are semiotically and linguistically encoded in print media, by virtue of their being naturalized in the mainstream discourse about gender, not only affect our experience of consuming news and enter- 
tainment but also define the construction of gender identities and create a gate-keeping mechanism that ultimately determines the extent to which communities become (or not) gender-inclusive.

English print media in Pakistan has though less audience yet it has a greater influence on opinion makers [2]. It carries these notions as well as influence of its unique sub-continental culture. In absence of any in-depth study on analyzing representation of women in media, the researcher intends to determine in a methodical and in-depth fashion that how females are represented in the context of Dawn and The News, two immensely popular publications in Pakistani media and whether this representation is being changed over a period of 6 years. To expect and determine a change in media is significant keeping in view the political changes held over a period of the last six years. A liberal media policy was introduced by a military coup [3]. Liberty propounded to media was at an early stage when data were first collected for a purpose of dissertation [4]. Over a period of 6 years, media showed a freedom of expression in all its genres: electronic and print. Present study aims to find whether this freedom of expression benefited woman or not in acquiring equality.

In order to understand the representation of women in the media, first, researcher started by giving an overview of the previous research done in this area in the section below. It was easier to classify it and organize this information by grouping related topics around a focus given by the most relevant terms in this study. Second, the methodology used in this study was explained in detail. Third, the results shown by the data were presented. Finally, these results were analyzed and some preliminary conclusions will be drawn that will point the researcher in the direction of further research for this project.

\section{Literature Review}

\subsection{Feminism, Gender and Language}

Feminists view women as an oppressed group treated differently. Patriarchal society runs to benefit men and women are subject to not only personal but also institutional discrimination. Language as a tool in constructing and reflecting gender inequality is a claim of feminist linguists [5]. Reference [6] approves Chalmer's assertion as cited in [6] that "theory precedes observations" by saying "when there are a sexist language and sexist theories culturally available, the observation of reality is also likely to be sexist". A language "is sexist if its use constitutes, promotes or exploits an unfair or irrelevant or impertinent distinction between the sexes" [7]. In language, sexism includes "words, phrases, and expressions that unnecessarily differentiate between females and males or exclude, trivialize, or diminish either gender” [8].

Origin of this phenomenon is not mere accident as reference [6] observes in her book "Man Made Language". In her view language was made by man and it represents the biasness towards the status of women which in her opinion is derived from the status of male. Male, in English Language, as observed by [9] is taken as norm whereas female is deviant. Language presents non-parallel structure "man \& wife", generics as "man" \& "he" and lexical asymmetry as in "teacher-lady teacher' where affix is used to make woman as marked form-a deviation from male standard norm. It also implies that profession belongs to male normally. According to [10], use of affixes "lady” and "-ess", “-ette”, “-enne”, “-trix” in terms used for female as "authoress", "poetess", "comedienne", "aviatrix" have a sense of lack of seriousness about women when compare with terms used for male. An empirical evidence of [6] shows how male-generics are false as they render women invisible. Most famous examples are "man is primate" (where word "man" tries to be generic) and "man is a mammal which breastfeeds his young" (where generic fails completely to include both sexes) [11] [12]. Feminists carried out empirical studies to confirm it and studies showed that reading masculine forms as generics, image of man comes to reader's mind [13] [14]. Evidence suggests that lexical choices influence the way we view the world.

Language does not only construct, but also it mirrors patriarchal society. Evidence comes from the resistance to accept the alternatives created [15]. Acceptance of gender-neutral alternatives was found in female then in male as studies of [16] and [17] report after analyzing attitude of students towards alternatives. To quote an example, "chairman" was replaced by "chairperson" but media continued use of "chairman" when reporting about a male but used gender-neutral term to report a female [4], thus contaminating the neutral term. Feminists view this practice as indicating high status of men in a society where it is taken atypical for women to have a high-status. Attempts to reform language were devalued and diminutive. To reform the language, [18] feels that change has to be at institutional level.

Gender and language has long been subject of interest for researchers in the West. Reference [19] explored the way language can be used to produce the sense of a person being powerless. In this way sexist language is a 
tool to maintain and enhance the power relations in society. Linguistic representation examined before was done in terms of convention of naming [6] [20], titles, terms of address and vocabulary lacking equivalence [4] [5] [21] [22], generic "he" and "man" that excludes women and semantic derogation that happened with the terms related to women more often than those of men [4] [23].

Besides sexism in language, opponents of women's rights employed claims of culture or tradition to rationalize women subordination [24]. Norms of respectability underpin gender inequality [25]. This purpose is served by the discourse of respectability which renders women into fixed roles of mother or wife. Reference's [26] case study of Namibian women explored the way respectability discourse influence opportunities of choice. Their findings showed that the concept of "real woman' specified the 'right' ways of living by being mothers or wives and removes the status from women who are single or choose independent life by considering them 'unrespectable'”.

\subsection{Gender in Print Media}

The role of women in society and their representation in media has been the focus of researchers over the last 25 years [27] [28]. Researchers analysed media's power to represent and perpetuate gender constructions in different genres. It is investigated how media construct gender at workplaces [29]-[31]. In politics, women political leaders' achievements take less coverage than her appearance and are usually trivialized [32]. Whereas studies on female athletes show an issue of underrepresentation, an emphasis on femininity and negative aspects and highlighting of their physical appearance more than of their competence [33]. Women with a higher social status as business executives receive the same coverage as she does in other fields. Though their acceptable visibility may resist the stereotypes prevailing in society [34] still a critical discourse analysis of US business press discourse by [35] found the image of women executives fractured as compared to that of men. Advertising plays a crucial role in strengthening stereotypes about women as was found in the studies of [36]-[39].

\subsection{Women in Crime Reporting Media}

In crime reporting, media may distort the reality either by representing extensively or by portraying negatively [40]. Studies of [41]-[45] show a negative and exaggerated depiction of women in crime news-reports. A content analysis of ([45]: 371) of two Pakistani news channels "Express News" and "Dawn News" uncovered the role of media being "lethargic and biased". A data of four months' news-reports revealed an extensive coverage of sexual harassment in both channels with "Express' being more negative than "Dawn" to seek sensationalism. Though this study didn't show clearly what linguistic devices were used to serve the purpose. Three rape cases studied by [42] appeared in Pakistani English newspapers to explore the role of media in promoting female sexuality. Study highlighted the distinctive attitude of press towards women of different classes. An analysis of [41] of images of female criminal showed women represented as witches. Another analysis of [43] analyzed headlines of crime reports published (Feb. March and April 2006). Their findings showed gender specific description in crime reporting. Women victims have no self-identity and represented in traditional roles ([43]: 33-35). While in another analysis of four cases with two on women victims and two on women offenders, researcher analysed words and phrases used in stories, explored gendered themes and found stereotypical attributes given to women [44]. Women are defined by appearance and their relation with men whereas men are described in terms of activities and accomplishments [44].

This effect of prism in media does not end here. Few studies [46]-[50] show how the blame game is played in print. Blaming victim, according to [51] is one of the rape myths which are used to neutralise perpetrator's behaviour by shifting blame to victim. A study of [46] about publicity given to rape cases in 1993 is based upon observations made of British trials for four months. Her analysis showed how press distorted the picture to give an image of men being unfairly accused of rape whereas female victims are often blamed for domestic violence. Studies [47] [48] found reporters blaming female victims of homicide. Reporters fail to place responsibility on perpetrator [47] and if responsibility of crime is placed, it is followed up by making excuses [49] as cheating on partner or provocation of attack by victim's initiative [52]. Reference [50] reviewed [49]'s study to see whether representation was changed or was consistent with previous practice. Her study presented slight increase in victim blaming, a large increase in positive representation of victim but also an increase in using positive terms for perpetrator. Thus the language was used to undermine the trustworthiness of complainant. Referring to the term "alleged victim", reference [53] objected the use for victim as it was the victim who was alleging against "al- 
leged" perpetrator. But the term "alleged" cast the whole issue of claim into doubt. Later [54] found the same lexical choice for victim.

The language media use is "critical in constructing readers" perception of crime ([55]: 61). An analysis of the effect of passive voice used in crime reporting on male and female readers was done by [56]. They found that male readers found less harm to victim and less responsibility of offender. A study of Turkish press found the names of perpetrators missing in the headline of crime news [57]. Furthermore, such reporting reinforces powerful stereotypes related to "easy prey" [58], "ideal" victim and "ideal" criminal where the ideal victim stereotype is female, vulnerable and powerless than perpetrator ([59]: 96). These images affect the way perpetrator and society perceives violence against women and the inference that victims are in part responsible for re-traumatise them further [60].

Media discourse analysis is not a widely researched field in Pakistan. Most of the previous studies were quantitative in nature. These and others based on qualitative in-depth study on linguistic analysis ignored the way lexical and grammatical choices in a language play a role in constructing a particular image. Present study analyses current representation and compares the results with previous data of unpublished dissertation collected in 2007. For this purpose similar methods were employed to look for similarities and differences. The time of present study is quite significant as press has been enjoying freedom for more than a decade and masses are excited and hopeful from new political leadership to bring positive changes. In this scenario, it is important to see what can be done to bring this change in the lives of women also.

\subsection{Research Questions}

1. How women are represented linguistically in crime reports in Pakistani English newspapers?

2. How does present (2014) portrayal differ from that of 2007 ?

\section{Research Design}

Following a Pragmatic paradigm, a mixed method approach following [61]-[64] was adopted in data analysis. For an in-depth study, qualitative and quantitative measures were used to illicit answer of above research questions.

\subsection{Method of Data Collection}

For the purpose of analysis, daily newspapers were selected as they are a major source of information about social and political activity in Pakistan and are likely to be more news-sensitive than magazines. The researcher chose newspapers published in English as the interest was in exploring the way the English language can affect the representation of women in print media in Pakistan.

First, sample was taken from English newspapers Daily Dawn and The News, published in March 2014. This sample was compared with a previous sample taken from same newspapers from March 2007. Probability sampling, a form of random sampling, was chosen to select newspapers of ten days to avoid any bias as this technique gives each newspaper equal chance to be selected and for the sake of simplicity [65]. To make it systematic researcher gave each newspaper a number i.e. listed them from 1 - 60. Sample size was decided as $n=20$ whereas interval size $k=3$. Researcher chose first newspaper as starting point and by selecting every $3^{\text {rd }}$ newspaper we got our sample as newspapers of dates 16, 19, 22, 25, 28, 31, 3, 6, 9, 12, 15. News reports focusing on crime involving men and women as primary subjects of crime either being victim or perpetrator were collected to ensure that articles were representative of gender in crime reports. These stories were used for discourse analysis.

\subsection{Method of Data Analysis}

For the purpose of analysis, Content analysis and Discourse analysis were adopted. Content Analysis was selected to see the frequency of visibility of men and women.

Analytical Approaches: Feminist Stylistics: For a qualitative analysis, first, news articles were analyzed using discourse analysis method. For this, all news articles were analysed. In this study the researcher used [10] approach to "Feminist Stylistics" to serve the purpose better as it deals with the analysis of linguistic features but with a feminist view and a special focus on the way women are represented in different texts. This approach 
towards feminist analysis of linguistic units goes beyond linguistic stylistics which lays stress on identification of patterns of usage in speech and writing. For her, stylistics can make the readers aware of aspects of text like lexical and grammatical choices, which a simple close reading cannot do. But stylistics does not consider the text in the context either of its production or critical reception. This approach considers extra textual aspects of text such as gender in textual analysis and incorporates the issue of gender into stylistics. In spite of counting nouns and verbs, she draws on the theories of linguistics which encourage focus on issues of feminist concern. Feminist stylistics lead stylistics to an analysis of socioeconomic factors which have allowed that language to appear and it also foregrounds the factor of gender in the text. It shows how the linguistic forms contribute to produce a character as powerless and how women are represented in language by using "false generics" [18].

In order to do this, feminist stylistics is adopted. A list of the steps taken for this analysis is given below.

1. Internal analysis of the text:

a) Analysing text at word, sentence and discourse level to look for patterns and irregularities in the representation of females in terms of using sexist language.

b) Examine these observations and offer insights into the semantic relations between some lexical items and the text as a whole.

At this level, this data was coded quantitatively as well to find out the frequency of themes emerging.

2. Positioning the texts in relation to genres:

a) Understand discoursal objectives within the chosen newspapers.

b) Establish the relation of text and their orientation.

3. Identify some discourses operating within the representation of female (and male) subjects within these texts.

\section{Results and Discussion}

While analysing the data, gendered patterns are appeared in crime reporting. Asymmetry is revealed in reporting women as compared to men.

\subsection{Naming Convention}

Naming practices are found different for men and women as shown in Table 1.

The Dawn shows a significant increase in use of full name for males but this use fell to almost half for females. The News shows a large increase for the same feature for male and a slight increase for female. Use of last name in crime reports is comparatively low than use of full name or first name and shows a mixed mood in both newspapers: in Dawn it show decrease and in The News it gives an increased value for both sexes. A significant increase is found in use of first name of males in Dawn for whom The News shows about hundred percent increase. For female, use of first name in the Dawn is lesser than it was observed in previous results but this use is increased in The News.

\subsection{Reporting Women in Terms of Age}

Women victims are described in terms of their age while men are not reported in the same vein as described in Table 2.

In Dawn, there is a significant increase in using age as reference while reporting male as compared to an increase in use for female whereas The News shows an almost equal increase in use for both.

\begin{tabular}{|c|c|c|c|c|c|c|c|c|c|c|c|c|}
\hline \multirow{3}{*}{ Newspapers } & \multicolumn{4}{|c|}{ Full Name } & \multicolumn{4}{|c|}{ Last Name } & \multicolumn{4}{|c|}{ First Name } \\
\hline & \multicolumn{2}{|c|}{ Male } & \multicolumn{2}{|c|}{ Female } & \multicolumn{2}{|c|}{ Male } & \multicolumn{2}{|c|}{ Female } & \multicolumn{2}{|c|}{ Male } & \multicolumn{2}{|c|}{ Female } \\
\hline & 2007 & 2013 & 2007 & 2013 & 2007 & 2013 & 2007 & 2013 & 2007 & 2013 & 2007 & 2013 \\
\hline Dawn & 46 & 63 & 27 & 15 & 2 & 1 & 12 & 1 & 17 & 34 & 37 & 5 \\
\hline The News & 20 & 90 & 11 & 14 & 1 & 2 & - & 2 & 9 & 110 & 8 & 23 \\
\hline
\end{tabular}




\subsection{Reporting Women in Terms of Relation}

Women victims are referred to their relation with men. This is also unusual for male victim or perpetrator as shown in Table 3.

There is a significant increase in reporting men in terms of relation over a period of 7 years. The News also reports men at few places in the same vein as it reports women but here number of women reports showing their relation to men and marital status doubled.

\subsection{Reporting in Terms of Profession}

Male victim or offenders are reported with a reference to their profession. Reports about female victim find less opportunity to be termed by profession as shown in Table 4 .

A slight decrease is observed in description of male in terms of profession in Dawn but a substantial decrease is found in report about female in terms of profession. Representation of male supplemented with professional information is increased in The News whereas women are excluded completely.

\subsection{Asymmetrical Description of Women}

Findings show that reporting about women used less sexist terms in Dawn over this period but it increased in The News as shown in Table 5.

Table 2. Gender representation in terms of age.

\begin{tabular}{|c|c|c|c|}
\hline Newspaper & N/Male & N/Female & Illustration \\
\hline Dawn (2007) & --- & 4 & $\begin{array}{c}\text { “22-year-old”-20/3 } \\
\text { “Twenty-five year-old”-23/3 }\end{array}$ \\
\hline Dawn (2013) & 20 & 12 & $\begin{array}{c}\text { “in her 30’s”-19/3 } \\
\text { “Karamat (25); Ali Riaz (26) -25/3 } \\
\text { “4-year-old boy”; “64-year-old grand-mother”-28/3 }\end{array}$ \\
\hline The News (2007) & ---- & 1 & “19-year-old”_-7/4 \\
\hline The News (2013) & 15 & 14 & $\begin{array}{c}\text { “A 22-year-old girl”-25/3 } \\
\text { “An 18-year-old girl was kidnapped”-31/3 }\end{array}$ \\
\hline
\end{tabular}

Table 3. Gender representation in terms of relation/marital status.

\begin{tabular}{|c|c|c|c|}
\hline Newspaper & N/Male & N/Female & Illustration \\
\hline Dawn (2007) & - & 5 & $\begin{array}{l}\text { "Daughter of "- }-20 / 3 \\
\text { "Was his wife"- }-29 / 3 \\
\text { "Daughter of" }-29 / 3\end{array}$ \\
\hline Dawn (2013) & 3 & 5 & $\begin{array}{l}\text { "Father of three” } 19 / 3 \\
\text { "Man kills 55-year-old wife”; "mother of four"-19/3 } \\
\text { "Father of five”-25/3 } \\
\text { "Mother"; "grand-mother"-28/3 } \\
\text { "Mother of three"-6/4 }\end{array}$ \\
\hline The News (2007) & - & 9 & $\begin{array}{c}\text { "Daughter of”-26/3 } \\
\text { "Wife of”, “director’s wife”-29/3 } \\
\text { "Daughter of”, “daughters of”- }-4 / 4 \\
\text { "Man accused of killing wife" }-13 / 4 \\
\text { "Mother of registrar"-13/4 }\end{array}$ \\
\hline The News (2013) & 4 & 18 & 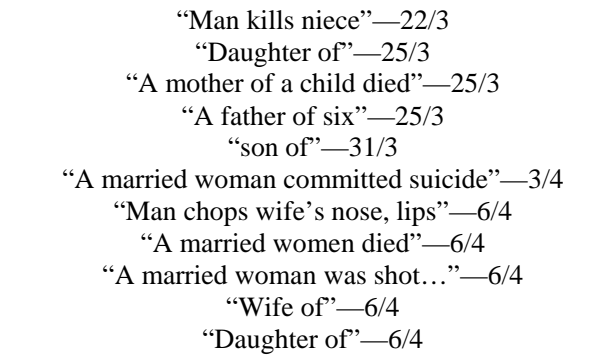 \\
\hline
\end{tabular}


Table 4. Gender representation in terms of profession.

\begin{tabular}{|c|c|c|c|}
\hline Newspaper & N/Male & N/Female & Illustration \\
\hline Dawn (2007) & 23 & 12 & $\begin{array}{c}\text { "District monitoring officer"-17/3 } \\
\text { "House matron”-20/3 } \\
\text { "Sanitary worker"-20/3 } \\
\text { "Daughter of journalist"-20/3 }\end{array}$ \\
\hline Dawn (2013) & 19 & 1 & 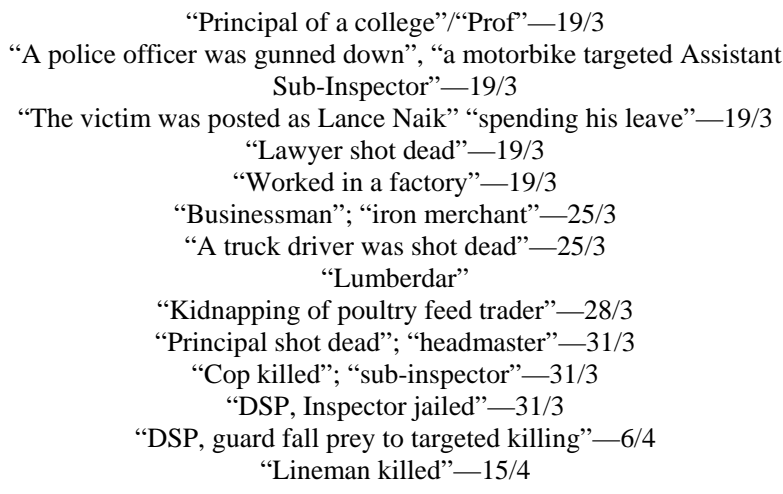 \\
\hline The News (2007) & 3 & --- & $\begin{array}{l}\text { "Daughter of Naik"-26/3 } \\
\text { "Wife of director"-29/3 }\end{array}$ \\
\hline The News (2013) & 25 & 1 & 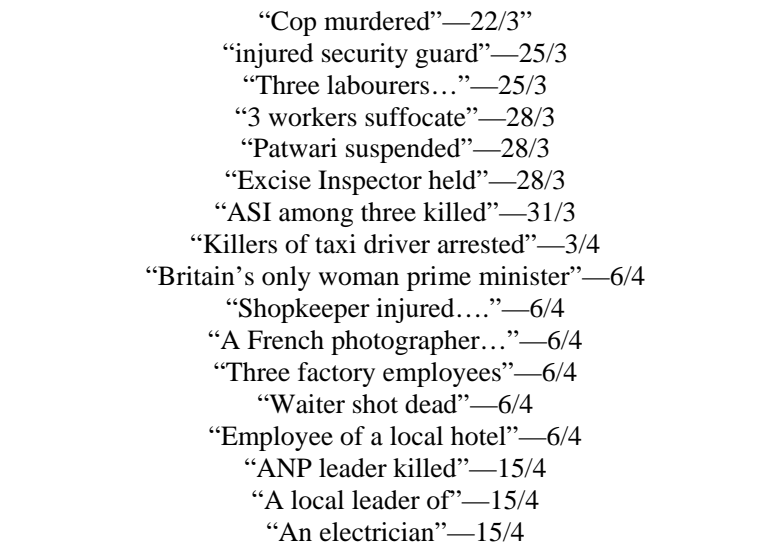 \\
\hline
\end{tabular}

Table 5. Use of asymmetrical (sexist) terms.

\begin{tabular}{|c|c|c|c|}
\hline \multicolumn{2}{|l|}{ Dawn } & \multicolumn{2}{|c|}{ The News } \\
\hline 2007 & 2013 & 2007 & 2013 \\
\hline$N=6$ & $\mathrm{~N}=4$ & $\mathrm{~N}=1$ & $\mathrm{~N}=4$ \\
\hline $\begin{array}{l}\text { "women teachers", “headmistress", } \\
\text { "female teachers"-(17/3) } \\
\text { "watchman"-20/3 } \\
\text { "woman journalist", } \\
\text { “female suicide bomber"-23/3 }\end{array}$ & $\begin{array}{l}\text { “Gunmen”-19/3 } \\
\text { “Spokesman”-19/3 } \\
\text { "Newsman”-19/3 } \\
\text { “Lineman”-15/4 }\end{array}$ & “Lady teachers" - 29/3 & $\begin{array}{l}\text { “Female students"-28/3 } \\
\text { “Spokesman”-6/4 } \\
\text { “Spokesman”-6/4 } \\
\text { “Spokeswoman-6/4 } \\
\text { “Gunmen”-15/4 }\end{array}$ \\
\hline
\end{tabular}

Women are referred to in a different way than the way men are. News-stories about women emphasize physical features and marital relation. They are defined by their relation with other males. They are referred in terms of their relation to other males. It seems they acquire a satellite status rather than having their own identity. Like the "real woman" of [26], they are identified as mothers, daughter, and wives, even as nieces but not as what they are. "Mother of three" or "mother of four" highlights the helplessness of children left behind. "A mother of a child" gives an impact of great loss of the child. Such reporting arouses sympathy in audience but it diverts the 
focus from victim to others who are enjoying life as discussed by [44]. One striking feature was noticed that their marital status is highlighted more now than before. "A married women committed suicide" has the connotation that she has spoiled a home by giving up. It seems unnecessary to use the adjective of "married" which was found present frequently. Asymmetry arises when male perpetrator is described as "man" but female victim is mentioned as "wife". This asymmetry shouldn't be taken a commonplace practice; its frequent use shapes a discourse to be taken as normal and constructed reality. Furthermore, a focus on unnecessary details of appearance and relation with other men moves readers' attention away from serious issues.

Supplementing a crime report with profession of victim gives an incremental effect to the loss. It is not a loss of a life anymore, it is rather a loss of an active and useful member of society as is obvious in examples "cop murdered", lawyer shot dead" and "principal shot dead". In absence of such worth in reports about women, female victims may be taken with a light air. Again finding with an emphasis on women's traditional role of mother, wife and daughter and ignoring their powerful and high status position in professional lives is in line with [66]. It strengthens the stereotype that women are best suited for caretaking role. Trend shows more emphasis on description of profession while reporting men. On the other hand total exclusion of women from description of profession signals an absence of professional women in Pakistan. It strengthens stereotype when compared with findings related to representation involving marital status and relation with man that women cannot bet good worker. They are fit for roles of nurturing mother, satisfying sexually as wife or dependent in a role of daughter. Where she was presented as professional in one news in "Britain's only woman prime minister", the whole emphasis is on singling her out as some deviant, abnormal example.

Another striking finding of present data is blaming victim in reports of on domestic violence. Though reporter or authority spokesperson placed responsibility on male perpetrator but this is followed up by making excuses and highlighting "for honour". It seems as male's honour is also attached with female and she has double responsibility to take care of that perhaps male can't do. Both reports highlighted the phrase "for honour" and gave reasons as perpetrators had "suspicion" that victim had illegitimate relation. Whether victims were guilty or not, the fact is that they were dead at the hands of their loved ones. This finding confirms the previous findings in other contexts [47]-[49].

\section{Conclusions}

Comparative analysis of crime reporting in Pakistan revealed that media has grown overall balanced and a trend towards non-sexist discourse emerged. An inclination is felt towards non-sexist discourse especially in the categories of naming convention and description of age. Whereas the categories of describing marital status and profession of victim are concerned, both newspapers lag behind an ideal state of equality. Dawn maintained previous practice of a comparatively balanced view while the news displayed a tendency towards asymmetrical representation of males and females as perpetrators and victims.

Pakistani media is enjoying freedom and it is expected to utilize this freedom in advocating and practicing justice and equality while reporting disadvantaged groups of society, women being one of them. Results of present study indicate a positive change at some places and hope for the same change at other places as well.

"Women in media" is a field with potential for future researchers. It needs to explore the relationship of representation of women in crime reporting and impact on cognitive patterns of reader's mind. As present study focused on comparison of women representation in newspapers over a period of seven years in two national newspapers, it did not explore the influence that such reporting may exert on the minds of readers and victims. Thus, present study provides ground for further research in this field. A qualitative study using interviews is recommended to explore effects of reporting.

\section{References}

[1] Jewkes, Y. (2011) Media and Crime. 2nd Edition, Sage, London.

[2] Sultana, N. (2009) The Role of Media in the Development and Promotion of English in Pakistan. PhD. Thesis, National University of Modern Languages, Islamabad.

[3] Iqbal, Z. (2012) Media and Musharraf: A Marriage of Convenience. European Scientific Journal, 8, 5-8.

[4] Yasmin, M. (2007) How Are Women Represented in Pakistani English Newspapers? MA. Thesis, University of Reading, Reading.

[5] Lakoff, R. (1975) Language and Women's Place. Harper \& Row, New York. 
[6] Spender, D. (1980) Man Made Language. Routledge, London.

[7] Vetterling-Braggin, M. (1981) Sexist Language: A Modern Philosophical Analysis. Littlefield Adams, Totowa.

[8] Parks, J.B. and Roberton, M.A. (1998) Contemporary Arguments against Nonsexist Language. Blaubergs (1980) Revisited. Sex Roles, 39, 445-461. http://dx.doi.org/10.1023/A:1018827227128

[9] Wodak, R., Ed. (1997) Gender and Discourse. Sage, London.

[10] Mills, S. (1995) Feminist Stylistics. Routledge, London.

[11] Moulton, J. (1981) The Myth of the Neutral “Man”. In: Vetterling-Braggin, M., Ed., Sexist Language, Littlefield and Adams, Paterson, 100-115.

[12] Mercier, A. (1995) A Perverse Case of the Contingent A Priori: On the Logic of Emasculating Language. (A Reply to Dawkins and Dummett). Philosophical Topics, 23, 221-259. http://dx.doi.org/10.5840/philtopics199523212

[13] Martyna, W. (1983) Beyond the He/Man Approach: The Case for Non-Sexist Language. In: Thorne, B., Kramarae, C. and Henley, N., Eds., Language, Gender and Society, Newbury House, Rowley, 25-37.

[14] Gygax, P., Gabriel, U., Sarrasin, O., Oakhill, J. and Garnham, A. (2008) There Is No Generic Masculine in French and German: When Beauticians, Musicians and Mechanics Are All Men. Language and Cognitive Processes, 23, 464-485. http://dx.doi.org/10.1080/01690960701702035

[15] Mucchi-Faina, A. (2005) Visible or Influential? Language Reforms and Gender (In)equality. Social Science Information, 44, 189-215. http://dx.doi.org/10.1177/0539018405050466

[16] Parks, J.B. and Roberton, M.A. (2004) Attitudes toward Women Mediate the Gender Effect on Attitudes toward Sexist Language. Psychology of Women Quarterly, 28, 233-239. http://dx.doi.org/10.1111/j.1471-6402.2004.00140.x

[17] Swim, J.K., Mallett, R. and Stangor, C. (2004) Understanding Subtle Sexism: Detection and Use of Sexist Language. Sex Roles, 51, 117-128. http://dx.doi.org/10.1023/B:SERS.0000037757.73192.06

[18] Cameron, D. (1985) Feminism and Linguistic Theory. Macmillan, London.

[19] Burton, D. (1982) Through Dark Glasses through Glass Darkly. In: Carter, R., Ed., Language and Literature, Allen and Unwin, London, 195-214.

[20] Miller, C. and Swift, K. (1976) Words and Women: New Language in New Times. Anchor, New York.

[21] Penelope, J. (1990) Speaking Freely: Unlearning the Lies of the Fathers’ Tongues. Pergamon, New York.

[22] Pauwels, A. (2001) Spreading the Feminist Word: The Case of the New Courtesy Title "Ms". In: Marlis, H. and Hadumod, B., Eds., Gender across Languages: International Perspectives of Language Variation and Change, Benjamins, Amsterdam, 137-151.

[23] Schulz, M. (1990) The Semantic Derogation of Women. In: Cameron, D., Ed., The Feminist Critique of Language, Routledge, London, 134-147.

[24] Becker, H. (2007) Making Tradition: A Historical Perspective on Gender in Namibia. In: LaFont, S. and Hubbard, D., Eds., Unravelling Taboos: Gender and Sexuality in Namibia, Gender Research and Advocacy Project, Legal Assistance Centre, Windhoek, 22-38.

[25] Fernando, W.D.A. and Cohen, L. (2014) Respectable Femininity and Career Agency: Exploring Paradoxical Imperatives. Gender, Work and Organization, 21, 149-164. http://dx.doi.org/10.1111/gwao.12027

[26] Khumalo, E.K., McKay, H.K. and Freimund, W. (2015) Who Is a “Real Woman”? Empowerment and the Discourse of Respectability in Namibia’s Zambezi Region. Women's Studies International Forum, 48, 47-56. http://dx.doi.org/10.1016/j.wsif.2014.10.002

[27] Byerly, C.M. (1999) News, Feminism, and the Dialectics of Gender Relations. In: Meyers, M., Ed., Mediated Women: Representations in Popular Culture, Hampton Press, Cresskill, 383-404.

[28] Meyers, M. (1999) Fracturing Women. In: Meyers, M., Ed., Mediated Women: Representations in Popular Culture, Hampton Press, Cresskill, 3-23.

[29] Mazza, C. and Alvarez, J.L. (2000) Haute Couture and Prêt-à-Porter: The Popular Press and the Diffusion of Management Practices. Organization Studies, 21, 567-588. http://dx.doi.org/10.1177/0170840600213004

[30] Czarniawska, B. and Rhodes, C. (2006) Strong Plots: Popular Culture in Management Practice and Theory. In: Gagliardi, P. and Czarniawska, B., Eds., Management Education and Humanities, Edward Elgar, Cheltenham, 195-218. http://dx.doi.org/10.4337/9781845429928.00021

[31] Rhodes, C. and Parker, M., Eds. (2008) Images of Organizing in Popular Culture. Special Issue of Organization, 15, 627-637.

[32] Mavin, S., Bryans, P. and Cunningham, R. (2010) Fed-Up with Blair's Babes, Gordon’s Gals, Cameron's Cuties, Nick’s Nymphets: Challenging Gendered Media Representations of Women Political Leaders. Gender in Management: 
An International Journal, 25, 550-569. http://dx.doi.org/10.1108/17542411011081365

[33] George, C., Hartley, A. and Paris, J. (2001) The Representation of Female Athletes in Textual and Visual Media. Corporate Communications: An International Journal, 6, 94-101. http://dx.doi.org/10.1108/13563280110391007

[34] Powell, G.N. (1999) Reflections on the Glass Ceiling: Recent Trends and Future Prospects. In: Powell, G.N., Ed., Handbook of Gender \& Work, Sage, Thousand Oaks, 325-345. http://dx.doi.org/10.4135/9781452231365.n17

[35] Krefting, L.A. (2002) Re-Presenting Women Executives: Valorization and Devalorization in US Business Press. Women in Management Review, 17, 104-119. http://dx.doi.org/10.1108/09649420210425255

[36] Chafai, H. (2007) Gender and the Language of Advertising. A Sociolinguistic Analysis of Women's Representation in British and Moroccan Magazine Advertisements. Thesis. http://repositorium.sdum.uminho.pt/bitstream/1822/7921/3/Thesis-Habiba.pdf

[37] Piller, I. (2003) Advertising as a Site of Language Contact. Annual Review of Applied Linguistics, 23, 170-183. http://dx.doi.org/10.1017/S0267190503000254

[38] Plakoyiannaki, E. and Zotos, Y. (2009) Female Role Stereotypes in Print Advertising: Identifying Associations with Magazine and Product Categories. European Journal of Marketing, 43, 1411-1434. http://dx.doi.org/10.1108/03090560910989966

[39] Yasmin, M. (2014) Divas in Print: The Portrayal of Gender in Pakistani Print Media. http://www.academia.edu/3708436/Divas in Print The Portrayal of Gender in Pakistani Print Media

[40] Pizarro, J.M., Chermak, S.M. and Gruenewald, J.A. (2007) Juvenile “Super Predators” in the News: A Comparison of Adult and Juvenile Homicides. Journal of Criminal Justice and Popular Culture, 14, 84-111.

[41] Heidenson, F. (1996) Women and Crime. 2nd Edition, Macmillan, Basingstoke.

[42] Zia, A. (1994) Sex Crime in the Islamic Context: Rape, Class and Gender in Pakistan. ASR Publications, Lahore.

[43] Rasool, S. and Irshad, S. (2006) Use of Gender Specific Language in Crime Reporting. Journal of Gender and Social Issues, 5, 15-37.

[44] Meloy, M. and Miller, S. (2009) Words That Wound: Print Media’s Presentation of Gendered Violence. In: Humphries, D., Ed., Media and Violence against Women, Northeastern University Press, Boston, 29-56.

[45] Ahmed, S. (2014) Violence against Women: Media Representation of Violent Issues in the Perspective of Pakistan. Science International, 26, 367-371.

[46] Lees, S. (1995) Media Reporting of Rape: The 1993 British “Date Rape” Controversy. In: Kidd Hewitt, D. and Osborne, R., Eds., Crime and the Media: The Post-Modern Spectacle, Pluto Press, London, 107-130.

[47] Bullock, C.F. and Cubert, J. (2002) Coverage of Domestic Violence Fatalities by Newspapers in Washington State. Journal of Interpersonal Violence, 17, 475-499. http://dx.doi.org/10.1177/0886260502017005001

[48] Park, G.L. and Gordon, J. (2005) Domestic Violence Presentation Raises Awareness in Student Reporters' Stories. Newspaper Research Journal, 26, 113-118.

[49] Taylor, R. (2009) Slain and Slanderer: A Content Analysis of the Portrayal of Femicide in Crime News. Homicide Studies, 13, 21-49. http://dx.doi.org/10.1177/1088767908326679

[50] Maddox, A.M. (2010) When Love Turns Lethal: A Content Analysis of Intimate Partner Homicide in Print Media. Ph.D. Thesis, University of Central Florida, Orlando.

[51] Eschholz, S. and Vaughn, M.S. (2001) Police Sexual Violence and Rape Myths: Civil Liability under Section 1983. Journal of Criminal Justice, 29, 389-405. http://dx.doi.org/10.1016/S0047-2352(01)00104-0

[52] Berkeley Media Studies Group (2003) Distracted by Drama: How California Newspapers Portray Intimate Partner Violence. http://www.bmsg.org/pdfs/Issue13.pdf

[53] Poukchanski, A. (2011) Ripples from the First Stone. The Sydney Institute Quarterly, 39, 10-14.

[54] Judd, K. and Easteal, P. (2013) Media Reportage of Sexual Harassment: The Incredible Complainant. Denning Law Journal, 25, 159-180.

[55] Pollak, J.M. and Kubrin, C.E. (2007) Crime in the News: How Crimes, Offenders and Victims Are Portrayed in the Media? Journal of Criminal Justice \& Popular Culture, 14, 59-83.

[56] Henley, N.M., Miller, M.D. and Beazley, J.A. (1995) Syntax, Semantics, and Sexual Violence: Agency and the Passive Voice. Journal of Language and Social Psychology, 14, 60-84. http://dx.doi.org/10.1177/0261927X95141004

[57] Alat, Z. (2006) News Coverage of Violence against Women-The Turkish Case. Feminist Media Studies, 6, $295-314$. http://dx.doi.org/10.1080/14680770600802041

[58] Khan, N. and Abas, N. (2014) Smart Crime Science and Shabby Control Technologies. Proceedings of the 2nd International Conference on Computational and Social Sciences (ICCSS-2014), Rize, 26-28 August 2014, 695-711. 
[59] Custers, K. and Van den Bulck, J. (2013) The Cultivation of Fear of Sexual Violence in Women: Processes and Moderators of the Relationship between Television and Fear. Communication Research, 40, 96-124. http://dx.doi.org/10.1177/0093650212440444

[60] Esteal, P., Holland, K. and Judd, K. (2015) Enduring Themes and Silences in Media Portrayals of Violence against Women. Women's Studies International Forum, 48, 103-113. http://dx.doi.org/10.1016/j.wsif.2014.10.015

[61] Nuthall, G. (1999) Learning How to Learn: The Evolution of Students' Minds through the Social Processes and Culture of the Classroom. International Journal of Educational Research, 31, 139-256.

[62] Nuthall, G. (2007) The Hidden Lives of Learners. NZCER Press, Wellington.

[63] Black, L. (2007) Interactive Whole Class Teaching and Pupil Learning. Language and Education, 21, 271-283. http://dx.doi.org/10.2167/le679.0

[64] Graham, E.T. (2009) “She’s Black More than She’s a Woman”. A Mixed Method Analysis of the Construction of Gender and Psychological Outcomes among Black Female College Students. Ph.D. Thesis, University of Miami, Miami.

[65] Bryman, A. (2001) Social Research Methods. Oxford University Press, Oxford.

[66] Lee, T.L., Fiske, S.T., Glick, P. and Chen, Z.X. (2010) Ambivalent Sexism in Close Relationships: (Hostile) Power and (Benevolent) Romance Shape Relationship Ideals. Sex Roles, 62, 583-601.

http://dx.doi.org/10.1007/s11199-010-9770-x 